\title{
English in Asian Bilingual Education: From Hatred to Harmony
}

\section{A Response}

Amy B.M. Tsui

Department of Curriculum Studies, The University of Hong Kong, Pokfulam Road, Hong Kong

\section{Introduction}

Tickoo's paper outlined a very important aspect of bilingual education the politics of language, which has been defined by Brian Weinstein, in his book The Civic Tongue, as 'the relation between the distribution of language skills on the one hand and economic and political power and high status or prestige on the other', as well as 'the process of selecting dialects or separate languages for well defined functions and the economic and political effects of that choice' (1983:11). Tickoo delineated the paradoxical situation in most Asian countries, particularly that in India, in which English is 'much coveted and suspected' at the same time. He offered an educational alternative which is, in his words, 'capable of making the language (English) a shared resource for all its stakeholders', hence, changing the relationship between English and Indian languages from hatred to harmony. In reacting to Tickoo's paper, I shall try to address the question of whether educational solutions are capable of resolving language conflicts or not. I shall be referring to the history of bilingual education in Hong Kong as well as its present bilingual situation in the hope that the experience in Hong Kong may help to shed light on the question raised.

\section{Linguistic Paradox in Hong Kong}

The love-hate paradox delineated by Tickoo is very much alive in Hong Kong, although what the paradox embraces has undergone some changes in recent years. Until recently, the antipathy against English was very much associated with the colonial rule by the British. English is an official language in Hong Kong and until the last few years, many of the top government officials were British, despite the fact that $98 \%$ of the population is Chinese. The English language, therefore, had been seen as a symbol of colonial rule, political suppression, inequality, power and affluence, rather than as a means of communication. The conflict between the English language and the indigenous languages in Hong Kong, written Chinese and Cantonese, was epitomised by the Chinese Language Movement in 1974, in which many university students took to the streets to demand that Chinese be made an official language. It was only then that Chinese was recognised as an official language of Hong Kong. Prior to that, all government correspondence was in English, and all meetings of government bodies were conducted in English even when members attending the meeting were all Chinese. ${ }^{1}$ It is therefore not surprising that English was perceived by 
Hong Kong people as a threat to their ethnic identity and their allegiance to their country.

The love-hate relationship depicted by Tickoo is best illustrated by a study conducted by Pierson et al. (1980) on the attitudes of 466 secondary school students at Grade 10 from both English-medium and Chinese-medium schools. The study found that the strongest agreement from the subjects was on statements like 'When using English, I do not feel that I am Chinese anymore'; 'At times I fear that by using English I will become more like a foreigner'; and 'If I use English, it means I am not patriotic'. They agreed that 'English should not be a medium of instruction in the schools in Hong Kong' and yet they also agreed with statements like 'I wish that I could speak fluent and accurate English', 'I would take English even if it were not a compulsory subject in school'; 'The command of English is very helpful in understanding foreigners and their cultures'. In other words, they realised the pragmatic value of English and aspired to it, but they were negatively oriented towards English. As Kachru (1986: 131) observes, 'While emotional attachment may be to one language, pragmatic needs motivate not only the continued use of English, but its further expansion'. (see also Bickley, 1990; Fu, 1987). If we look at the history of bilingual education in Hong Kong, we will be suprised to find that the importance of learning the mother tongue and learning through the mother tongue, as well as maintaining equal emphasis between English and Chinese had been reiterated in almost every single educational document. Yet the rhetoric never seemed to be translated into action.

\section{Bilingual Education in Hong Kong: Rhetoric versus Reality}

Way back in the 1860s, Frederick Stewart, the first ever Inspector of Government Schools who was brought out by the Hong Kong Government from Britain to teach English and to supervise all government schools, strongly advocated that equal emphasis should be paid to Chinese and English in the curriculum, that English should not be learnt at the expense of Chinese, that there should not be any attempt to 'denationalise' the young people of Hong Kong. He wrote in the Annual Report in 1866 as follows:

I know of no more humiliating spectacle than to see boys, as we frequently do in Hong Kong, who know English much better than they do Chinese, who entirely neglect their own language when they begin to learn the other ... If there is anything which ought to be aimed at in connection with the School it is that this disgrace shall not attach to it. (Annual Report 1866, cited in Bickley, 1990: 294)

He recognised the difficulty that Hong Kong Chinese students faced in having to master two languages and to learn content subject through the medium of a foreign language. He also recognised that the latter will affect not only the quantity but also the quality of learning. He maintained that studying Chinese would help the Chinese to learn English better. Yet the words of a man who was described as 'the scholarly conductor', 'the originator and constructor' as well as 'the defender' of the Government System of Education (see Bickley, 1990: 293) were not materialised. 
In the 1930s, a British education inspector called Burney visited Hong Kong and commented that not enough attention was being paid to Chinese primary education, that English was taking up far too much time in the curriculum and that Chinese should be used as the medium of instruction. The conclusion that Burney drew as a result of his visit was that 'language education policy in Hong Kong should ensure that no school learner should lack a command of the mother tongue sufficient for all needs of thought and expression, and that their standard of English should be limited to the satisfaction of vocational needs' (see Lord, 1987: 4).

In 1973, the Education Green Paper, which is a consultation document prior to the release of the Education White Paper, which is a policy document, recommended that the language of instruction of lower secondary schools should be Chinese and that English should be taught as a second language. However, the White Paper which was released a year later, backed down from the recommendation and left the choice of instruction medium to schools.

In 1982, a panel of educationists visited Hong Kong and made a series of recommendations on educational policies in Hong Kong in what is commonly referred to as the Llewellyn Report. The same points were reiterated with regard to language policy; that too much time had been given to language instruction at the expense of other subjects in the curriculum; that many students found it impossible to master English at the level of proficiency required for intricate thinking and consequently, many resorted to rote learning. The Report queried whether it is possible to use a second language as the vehicle for delivering universal education in a largely monolingual society. ${ }^{2}$ It stated categorically that 'mother tongue is, all other things being equal, the best medium of teaching and learning. There are sound political, cultural and psychological reasons to support this proposition'. (p. 28) The Report suggested that 'the government should "impose" Cantonese as the medium of instruction in Forms I-III of all secondary schools (Grades 7-9) so that the first nine years of schooling will be in the "language of the heart"' (p. 29). It further suggested that the government should embark on a long-term project to change the attitudes of parents and employers towards Chinese as a medium of instruction. To achieve this, it proposed that there should be a scheme of positive discrimination in favour of schools opting for Chinese-medium instruction, both in terms of resources and also post-school opportunities, such as admissions to further study and the Civil Service.

The subsequent education policy report, Education Commission Report No. I (ECR 1) (1984), (that is, the first Report released by the Education Commission, an education policy making body) paid lip service to mother tongue education but decided against the recommendation made by the Llewellyn Report that Chinese should be mandated as a medium of instruction on the grounds that doing so would deprive students who can benefit from English-medium education of a chance to learn through English. It resorted yet again to the familiar tack of leaving the decision up to individual schools. Positive discrimination measures were watered down to providing Chinese-medium schools with two additional English teachers to allow teaching in smaller classes. It proposed that the medium of instruction labels for schools be removed so as 'to assure parents of children studying in schools which teach in Chinese that their child would not 
be placed at a disadvantage' (p. 46). The same points were reiterated in the two subsequent reports, ECR 2, released in 1986 and ECR 3, released in 1988. However, parents were not assured by the removal of labels and schools were not attracted by the provision of additional English teachers. The number of Chinese-medium schools continued to fall, or at best remained the same. This is because with all the rhetoric about mother tongue being the best medium for learning, there were no socioeconomic and political realisations to convince people that they were more than sheer rhetoric. At the education level, English is still crucial for admission to tertiary institutions. At the government level, although Chinese is also one of the two official languages, all government documents are drafted in English in the first instance and then translated into Chinese. Moreover, one of the most important criteria for civil service recruitment, particularly at the administrative officer level, is English proficiency, both spoken and written. At the business level, all jobs ranging from clerical staff to top-level management require English and for senior positions, a good command of English is essential. A good command of Chinese is but merely icing on the cake. In short, a monolingual English speaker can operate fully at all levels but not a monolingual Chinese speaker. Given the situation, it is not surprising that Chinese-medium education is simply not a viable alternative for parents and students.

In the past 40 years, there has been a general decline in the propotion of secondary schools which are Chinese-medium. In 1958 there were 74 Englishmedium schools and 89 Chinese-medium schools; by 1970 the numbers were 229 and 114 respectively and by 1988, 343 and 57 . There was, however, a sudden increase in the number of Chinese-medium schools in the early 60 s because of the setting up of The Chinese University of Hong Kong in 1964 to provide higher education for Chinese-medium school leavers. However, starting from the early 70s, as the University started to take in more and more English-medium school leavers in order to compete with its English-medium counterpart, The University of Hong Kong, the number of Chinese-medium schools started to decline again.

With the decolonisation of Hong Kong underway as 1997 approaches, manifested by the gradual replacement of top government officials by local Chinese, by more and more use of written Chinese and Cantonese in communications by the government (despite the fact that they are translations from the English original), by the participation in politics by local people with the first direction in place in 1991, and by the development of the Hong Kong identity, the antipathy against English as a purely colonial language is easing off. This change in perception can be seen in Pennington \& Yue (1994), who administered the direct attitude questionnaire in Pierson et al. (1980) to 285 Hong Kong secondary school students spanning Grades 7 to 12 .

They discovered that students no longer found English a threat to their ethnic identity and their allegiance to their country. They disagreed with the statements 'When using English, I do not feel that I am Chinese any more'; 'At times I fear that by using English I will become like a foreigner'; 'If I use English, it means I am not patriotic'. This change of attitude from apprehension to acceptance is very much a consequence of changes at the political front. The decolonisation of Hong Kong, however, does not make English any less important. Quite the contrary, it 
is becoming more and more important as Hong Kong has grown into a centre of international trade. This can be seen from the fact that the subjects' ratings remained unchanged for statements like 'I wish I could speak fluent and accurate English'; 'I would take English even if it were not a compulsory subject in the schools in Hong Kong', and 'The command of English is very helpful in understanding foreigners and their cultures'. Compared to 1980, there was increased acknowledgement of the pragmatic value of English, evidenced by the fact that English was seen by subjects in 1994 as contributing to the success of Hong Kong.

It is ironic that with the reiteration of the benefits of mother tongue education by the government, the rating for the statement 'English should not be used as a medium of instruction in Hong Kong schools' increased from 1.8 to 3.21 (almost $100 \%$ ), indicating that young people want English-medium education even more than before. This is understandable if we consider the emphasis that has been put on the importance of English in maintaining Hong Kong's status as a centre of international trade in the past decade. Since the $80 \mathrm{~s}$, businesses have been lamenting the lack of competent English speakers to keep the competitive edge, but their outcry grew stronger and stronger towards the late 80s. In 1990, a consortium of big hongs even launched The Language Campaign to call for the improvement of English standards. The school system was blamed for not being able to produce competent English speaking graduates. William Purves, the Chairman of the Hong Kong Bank Holdings, one of the largest and politically most influential banks in Hong Kong, wrote, 'I believe there are many reasons why Hong Kong's language skills are inadequate. Some of these lie in primary and secondary education. There is little doubt that fundamental improvements in the education system are long overdue' (Hong Kong Bank Language Foundation Work Report, 1993).

The call by businesses to improve the schooling system so as to produce graduates with English competence to meet their needs led the government to set up a working group in 1988 to review the measures that have been implemented to improve language standards and to make recommendations, most of which were taken on by the Education Commission, and incorporated into its Report No. 4 (ECR 4) (1990). One major observation that the group made was that the use of mixed code was one of the main causes of inadequate language standards and that its use in schools must be stopped. (Mixed code is a mixture of English and Cantonese which is used by both teachers and learners as a result of their inability to use English to teach and learn.) The Education Commission recommended that schools should be encouraged to use either purely Chinese or purely English as the medium of instruction. It also recommended that English should only be used as a medium of instruction where students could benefit from it. It estimated that about 30\% would benefit from English-medium education and $70 \%$ would benefit only from Chinese-medium education. It also recommended that an objective assessment be made at Primary 6 to differentiate those who would learn better through their mother tongue and those who could learn effectively through English, and schools will be inspected by the Advisory Inspectorate to ensure that no mixed code is taking place.

While the $30 / 70$ estimate is probably a more realistic target than requiring all 
students to be proficient in both languages, these recommendations drew heavy criticism from the public. The language streaming policy was considered divisive, elitist, and even a resurgence of colonial rule. This is hardly surprising because as Weinstein (1983: 14) observes, 'The language chosen as the medium of instruction at all levels of education contributes to patterns of access to the most prestigious and intellectually superior diploma-granting institutions'. And these diplomas and degrees are 'tickets permitting entrance to the professions, the best positions in business firms, and jobs in the civil service...' (ibid.) Since most tertiary institutions in Hong Kong are English-medium and even the only university which was set up specifically for Chinese-medium students has been taking in mostly English-medium students, and since all top level positions require a high level of English competence, it is all too clear who is going to benefit from the recommendations made by the Education Commission - the 30\% minority.

Understandably, when schools were given the freedom to choose the medium of instruction for their own schools, only a very small percentage went for Chinese-medium.

Although the number of schools choosing Chinese-medium for the 1995-96 school year has increased from $13 \%$ to $17.5 \%$ of the total, the number of English-medium schools has also increased, from $57 \%$ to $59 \%$. The target of a 30/70 divide proposed by ECR4 is still very far off, and probably will never be achieved.

ECR4 differs from the previous Education Commission Reports in that instead of leaving it entirely up to schools to choose their medium of instruction, 'guidance' and 'advice' will be given by the government to schools on which is the best medium of instruction on the basis of tests and inspections. By 1998, 'firm guidance' will be given to schools. The government has never explained what 'firm guidance' means or entails, but it is generally interpreted as stronger control by the government. Schools which have opted for English-medium are now trying out all sort of ways and means to ensure that they pass the test when they are inspected by the Advisory Inspectorate so that they will not be 'advised' to change to Chinese-medium.

The overemphasis on the importance of English and the responsibility placed on the school system to produce graduates with high English competence to serve the needs of business have created a great strain on schools. Attaining high English standards has become, even more so than before, a very important goal in education and for many the only goal in education. High English competence of a minority is acquired at the expense of the majority who are not only unable to join the ranks but are deprived of a decent education. As Tickoo points out, for the majority of students, English has remained a source of failure, frustration and low self-esteem, despite all the rhetoric about the importance of mother tongue education.

\section{Concluding Remarks}

From the history of bilingual education in Hong Kong, we can see that there has never been any doubt about the mother tongue education being the best language for the development of literacy, and that a second language or foreign 
language should never take over the role of the mother tongue. However, because measures to support mother tongue education have never been coupled with measures to recognise the importance of the mother tongue at the political and socioeconomic levels, mother tongue education has remained the poor cousin of English-medium education, or the 'concubine' of English-medium education, as the Chinese saying goes.

\section{Notes}

1. In fact, even now, all government correspondence is written in English in the first instance and then translated into Chinese.

2. Compulsory education was introduced in 1971 and nine-year compulsory education was introduced in 1978.

\section{References}

Bickley, G. (1990) Plus ça change, plus c'est la même chose: Attitudes towards English language learning in Hong Kong — Frederick Stewart's evidence. World Englishes 9 (3), 289-300.

Fu, G. (1987) The Hong Kong bilingual. In R. Lord and H. Cheng (eds) Language Education in Hong Kong (pp. 27-50).

Hong Kong Bank Language Foundation Work Report (1993), Hong Kong Bank publication.

Kachru, B. (1986) The power and politics of English. World Englishes 5 (2\&3), 121-40.

Lord, R. (1987) Language policy and planning in Hong Kong: Past, present, and (especially) future. In R. Lord and H. Cheng (eds) Language Education in Hong Kong (pp. 3-26).

Pennington, M. and Yue, F. (1994) English and Chinese in Hong Kong: pre-1997 language attitudes. World Englishes 13 (1), 1-20.

Pierson, H., Fu, G. and Lee, S.Y. (1980) An analysis of the relationship between language attitudes and English attainment of secondary school students in Hong Kong. Language Learning 30, 289-316.

Weinstein, B. (1983) The Civic Tongue. New York: Longman. 